\title{
An Iron Deficiency Anemia Case That Came with Raw Rice Consumption
}

\author{
Çiğ Pirinç Yeme Şikayeti ile Gelen Demir Eksikliği Anemi Olgusu
}

Ahmet Adil CAMLI, Cumali KARATOPRAK, Guven CETIN, Mehmet ZORLU, Murat ALAY

Department of Internal Medicine, Bezmialem Vakif University, Faculty of Medicine, Istanbul, Turkey

\section{ABSTRACT}

Pica is the chronic consumption of edible or nonedible materials that is thought to be caused by mental problems, pregnancy, or anemia. We wanted to report this case, which we have not seen in the literature before, of a pica patient who consumed raw rice due to iron deficiency anemia. A 26-year-old female patient was brought to the internal medicine polyclinic by her mother with complaints of consuming a bowl of raw rice ( 200 gr) every evening. The patient was treated with parenteral ferik hydroxide + sucrose complex $(2700 \mathrm{mg}$ ) for 5 days. After 15 days, when she came to control her will to eat raw rice had been lost completely. As a result, the attention of doctors and family members for pica due to treatable causes, such as anemia, will prevent many probable complications.

Key Words: Pica, raw rice, iron deficiency anemia

\section{ÖZET}

Pica; gebelik, mental bozukluk ve anemi gibi nedenlere bağlı olarak oluştuğu düşünülen yenilebilir veya yenilemez maddelerin kronik olarak tüketilmesidir. Literatür de demir eksikliğine bağlı olarak toprak yeme, buz yalama, sigara izmariti yeme gibi farklı pica örnekleri yayınlanmışsa da olgumuza benzer bir yayına rastlamadık. Burada 26 yaşında bir kadın hastada demir eksikliği anemisi sonucu 3 yıldır her gün bir kâse çiğ pirinç tüketen ve demir tedavisi verdiğimizde pirinç yeme isteği kaybolan gebe olmayan pika'lı bir olgu sunuldu. Sonuç olarak anemi gibi tedavi edilebilir nedenlere bağlı gelişen pika durumlarına karşı doktorların ve aile üyelerinin uyanık olması, gelişmesi muhtemel birçok komplikasyon'u engelleyecektir.

Anahtar Sözcükler: Pika, çiğ pirinç, demir eksikliği anemisi

\section{Introduction}

The symptoms of anemia are usually paleness, fatigue, and palpitation; however, sometimes, pica, spoon-nail, and blue sclera may be seen. Pica is the consumption of edible or nonedible materials that is thought to be caused by psychological problems, pregnancy, or anemia (1). The attention of doctors to pica cases, especially to treatable cases, such as anemia, can prevent many complications. Even though many pica cases have been reported, raw rice consumption due to anemia in non-pregnant women has not been reported in the literature. Therefore, we wanted to report this case of a patient who consumed raw rice every day due to iron deficiency anemia and, when given iron treatment, lost her will to eat raw rice.

\section{Case Presentation}

A 26-year-old woman was brought to the internal medicine polyclinic by her mother with the complaint of consuming a bowl of raw rice ( $200 \mathrm{gr})$ every evening. Her complaints began 3 years ago, and her will to eat raw rice had grown stronger ever since. Even though her family forbade it, she continued to consume it regularly. The patient did not have any other known disease and did not use any drug. In her physical examination, skin and conjunctival paleness was seen. Other 


\section{Table 1. Patient's Blood Parameters.}

Parameters

\begin{tabular}{|l|c|c|c|}
\hline White Blood Cell (103/uL) & 6.92 & 7.02 & 8.0 \\
\hline Hemoglobin (g\dL) & 8.0 & 10.1 & 11.4 \\
Haematocrit (\%) & 28.1 & 34.7 & 37.4 \\
Mean Corpusculer & 66.6 & 74 & 80 \\
Volume (fL) & & & \\
Platelet (103/uL) & 348 & 317 & 300 \\
Ferritin (ng/dL) & 3.3 & nt & nt \\
\hline not tested (n.t.) & & &
\end{tabular}

physical examination findings were normal. The laboratory tests were matching with iron deficiency anemia (Table 1). The peripheral blood smear was indicating iron deficiency anemia. Thus, the patient was diagnosed with pica caused by iron deficiency anemia. The patient was treated with parenteral ferik hydroxide + sucrose complex $(2700 \mathrm{mg})$ for 5 days. After 15 days, when she came to control her will to eat raw rice had been lost completely. In her following control tests, her anemia was seen to be cured, and in the next 2 months of follow-up, she did not show any will to eat raw rice again (Table 1). This case report was written after obtaining informed patient consent.

\section{Discussion}

Pica is a food disorder that has been known for centuries. It is commonly seen in women and children (2). Even though many hypotheses were developed to explain the pathophysiology of pica due to iron deficiency, none could explain it completely.

In the literature, many pica cases due to iron deficiency anemia have been reported. Eating materials, such as ice cubes (pagophagia), clay (geophagia), dried pasta (amylophagia), chalk, starch, paste, Kayexalate resin (resinphagia), tomatoes, lemons, cigarette butts, hair, lead, laundry starch (for example, Argo out of the box), ice tea, and elastic band, is reported (2-7).

Parameters, such as ethnicity, geographical region, and alimentation disorders, are important in the correlation between pica and iron deficiency anemia, according to studies (3-5). Several reported pica cases due to raw rice consumption are seen in pregnant women in different geographical regions (2). No case of raw rice consumption due to iron deficiency in non-pregnant women is seen in the literature.

In our reported case, the raw rice eating habit continued for 3 years. It is intriguing that the patient and her family did not consider this situation a disease. The family considered pica a bad habit, such as smoking, and tried to solve the problem by forbidding and restricting access to raw rice. However, if they considered the possibility that pica development could be caused by iron deficiency, 15 days of iron treatment could be enough for the treatment of the disorder instead of the years of effort she and her family spent.

\section{Conclusion}

The attention of doctors and family members for pica due to treatable causes, such as anemia, will prevent many probable complications.

Informed Consent: Written informed consent was obtained from the patient who participated in this case.

Peer-review: Externally peer-reviewed.

Author Contributions: Concept - C.K., A.A.Ç.; Design - A.A.Ç., G.C.; Supervision - C.K., M.Z.; Funding - M.Z.; Materials - M.A.; Data Collection and/or Processing - C.K.; Literature Review - A.A.Ç.; Writing - C.K.

Conflict of Interest: No conflict of interest was declared by the authors.

Financial Disclosure: The authors declared that this case has received no financial support.

Acknowledgements: We thank to S. Delecroix for translation consultancy.

Hasta Onamı: Yazılı hasta onamı bu olguya katılan hastadan alınmıştır.

Hakem Değerlendirmesi: Dış bağımsız.

Yazar Katkıları: Fikir - C.K., A.A.Ç.; Tasarım - A.A.Ç., G.C.; Denetleme - C.K.; Kaynaklar - M.Z.; Malzemeler - M.A.; Veri Toplanması ve/veya İşlemesi - C.K.; Literatür Taraması - A.A.Ç.; Yazıyı Yazan - C.K.

Çıkar Çatışması: Yazarlar çıkar çatışması bildirmemişlerdir.

Finansal Destek: Yazarlar bu olgu için finansal destek almadıklarını beyan etmişlerdir.

Teşekkür: Çeviri danışmanlığı için S. Delecroix’ye teşekkür ederiz.

\section{References}

1. Yildiz I. Iron deficiency anemia. Turk Arch Ped 2009; 44: 14-8.

2. Kettaneh A, Eclache V, Fain O, Sontag C, Uzan M, Carbillon L, et al. Pica and food craving in patients with iron-deficiency anemia: a casecontrol study in France. Am J Med 2005; 118: 185-8. [CrossRef]

3. Khan Y, Tisman G. Pica in iron deficiency: a case series. J Med Case Rep 2010; 4: 86. [CrossRef]

4. Muñoz JA, Marcos J, Risueño CE, et al. Iron deficiency and pica. Sangre (Barc) 1998; 43: 31-4.

5. Grivetti LE. Culture, diet and nutrition: selected themes and topics. BioScience 1978; 28: 171-7. [CrossRef]

6. Radhika MS, Nair KM, Kumar RH, Rao MV, Ravinder P, Reddy $\mathrm{CG}$, et al. Micronized ferric pyrophosphate supplied through extruded rice kernels improves body iron stores in children: a double-blind, randomized, placebo-controlled midday meal feeding trial in Indian schoolchildren. Am J Clin Nutr 2011; 94: 1202-10. [CrossRef]

7. Barton JC, Barton JC, Bertoli LF. Pica associated with iron deficiency or depletion: clinical and laboratory correlates in 262 non-pregnant adult outpatients. BMC Blood Disord 2010; 10: 9. [CrossRef] 